\title{
PEMBERDAYAAN MASYARAKAT MELALUI EDUKASI LINGKUNGAN DI DESA CINANGNENG
}

\author{
Movi Riana ${ }^{1}$, Achmad Nurul Azikri, Ausen Samalateh ${ }^{2}$. \\ movi.riana@uika-bogor.ac.id \\ Dosen Fakultas Keguruan dan Ilmu Pendidikan¹, Mahasiswa KKN Kelompok 01 Tahun \\ $2018^{2}$
}

\begin{abstract}
ABSTRAK
Kuliah Kerja Nyata (KKN) merupakan kegiatan pengabdian kepada masyarakat didaerah tertentu atau lembaga pendidikan, dilaksanakan secara kelompok, teritegrasi antar jurusan, terkoordinasi di tingkat fakultas, diutamakan kegiatan fisik dan nonfisik di segala bidang. Kegiatan KKN bertujuan untuk memberikan pengalaman kerja nyata di lapangan dalam bidang membentuk sikap mandiri dan tanggung jawab dalam pelaksanaan pekerjaan di lapangan. Selain itu, KKN juga bertujuan uintuk membantu masyarakat dalam meningkatkan taraf pengetahuan dan keterampilan sehingga diharapkan dapat meningkatkan kesejahteraannya. Kegiatan KKN dibagi menjadi empat tahap kegiatan, yaitu pembekalan, pelaksanaan, penyusunan laporan, dan evaluasi. Pelaksanaan KKN ini dimulai dari tanggal 7 Agustus 2018 sampai dengan 5 September 2018 di Desa Cinangneng, Kecamatan Tenjolaya, Kabupaten Bogor. Program kelompok di Desa Cinangneng merupakan program yang lebih menekankan kepada tema Pemberdayaan Masyarakat Melalui Edukasi Lingkungan Desa Cinangneng. Program fisik kelompok 01, antara lain : kerja bakti, perbaikan sarana prasarana penerangan jalan umum. Program non-fisik, antara lain : Sosialisasi Program KKN,Bimbingan belajar, Perayaan HUT RI "17 Agustus", Penyuluhan PHBS + CTPS, Pengajian ibu-ibu \& bapakbapak,Cek Kesehatan Gratis, Sosialisasi Menabung dalam 500 rupiah,Mengajar MI,PAUD,TPQ dan pesantren,Pembukuan ke warung, Bazar murah, Seminar hukum.
\end{abstract}

\section{Kata kunci : Edukasi, KKN, Program.}

\section{PENDAHULUAN}

\section{Keadaan Geografis}

Desa Cinangneng adalah salah satu desa di Kecamatan Tenjolaya yang mempunyai luas Wilayah 257.295 Ha. Jumlah Penduduk Desa Cinangneng Sebanyak 9.492 Jiwa, yang terdiri dari 4.522 Laki-Laki dan 4.970 Perempuan. Dengan Jumlah Kepala Keluarga Sebanyak 3.460 KK. Sedangkan Jumlah Keluarga Miskin (Gakin) $726 \mathrm{KK}$, dengan presentase
$21 \%$ dari Jumlah keluarga yang ada di Desa Cinangneng.

Desa Cinangneng Kecamatan Tenjolaya Secara Umum berupa dataran tinggi yang berada pada ketinggian antara $450 \mathrm{~m} \mathrm{~s} / \mathrm{d} 460 \mathrm{~m}$, di atas permukaan laut. Desa Cinangneng terdiri dari 6 (Enam) RW dan 23 (Dua Puluh Tiga) RT.. Batas-batas administratif Pemerintahan Desa Cinangneng kecamatan Tenjolaya adalah Sebelah Utara Desa Bojong Jengkol, Sebelah Timur Desa Situ Daun /Cihideung Udik, Sebelah Selatan Desa Cibitung 
Tengah, Sebelah Barat: Desa Cinangka. Terdapat beberapa sumber air yaitu dari Sungai Cinangneng (batas Desa Cinangneng dengan Desa Situ daun Kecamatan Tenjolaya), Sungai Cikalancing (batas wilayah dengan Desa Cinangka) Daerah Irigasi (D.I) Cimarayana, Daerah Irigasi (D.I) Citengah. Disamping itu ada pula beberapa sumber mata air yang bisa digunakan diantaranya : Mata Air Ciburial,Mata Air Cikondang.Mata Air Cimulang. Luas lahan berupa sawah teknis seluas : $150 \mathrm{Ha}$, Semi Teknis seluas : $48 \mathrm{Ha}$, Perikanan : $2 \mathrm{Ha}$, hutan Rakyat, $0 \mathrm{Ha}$, dan lahan lainya berupa pekarangan pemukiman $27 \mathrm{Ha}$.

\section{Keadaan Sosial}

Tenaga Kesehatan di Desa Cinangneng pada tahun 2016-2017 terbagi atas Medis/Dokter 1 orang, Keperawatan 1 orang, Bidan 1 orang, dukun beranak 2 orang, dan partisipasi masyarakat di bidang kesehatan sebanyak 24 orang Jumlah kelahiran bayi (persalinan) pada tahun 2013 adalah sebanyak = 48 jiwa, yang terdiri dari bayi lahir hidup sebanyak $=47$ jiwa, bayi lahir mati sebanyak $=$ 1 jiwa, dan Tahun 2013 sebanyak = 58 Jiwa

Di Desa Cinangneng tahun 2016-2017, jumlah guru dan murid tiap tahunnya mengalami peningkatan. Guru pada tahun 2014 berjumlah $=123$ orang. Guru ngajai /Guru sekolah Dengan jumlah murid Paud sebanyak =
150 orang, SD sebanyak 849 orang, SLTP $=750$ orang, SLTA sebanyak $=284$ orang.

Tantangan yang harus dihadapi dalam pembangunan kesejahtraan sosial meliputi proses globalisasi dan indrustrialisasi serta krisis ekonomi dan politik yang berkepanjangan. hasil sensus jumlah penandang cacat $=24$ orang, Keluarga Miskin social $=691$ orang, Keluarga rumah tidak layak huni $=121$ orang, Wanita rawan sosial ekonomi $=105$ orang, Keluarga rawan sosial ekonomi $=691$ orang, Pemulung $=5$ orang, Janda PKRI $=1$

Jumlah angkatan kerja pada tahun 2013 sebanyak $=1.878$ orang, jumlah pencari kerja lainnya sebanyak : 660 orang, sedang sisanya sebanyak : 660 orang belum mendapatkan pekerjaan. Pada bidang olahraga, Desa Cinangneng memiliki 4 klub olahraga diantaranya, klub sepak bola, Bola voli, Bulu tangkis, Basket masing-masing 1 klub. Pada bidang kebudayaan desa cinangneng memeiliki beberapa kelompok budaya dan kesenian di antaranya jaipong 1 klub dengan status pasif, pencak silat 2 klub dengan status pasif, Qasidah 23 klub dengan status aktif, Gambus 1 klub dengan status aktif, Orkes dangdut 1 klub dengan status aktif, Marawis 2 klub dengan status aktif. 


\section{METODE PENGABDIAN}

Tahapan pelaksanaan untuk kegiatan ini sebagai mana terlihat pada bagan berikut:

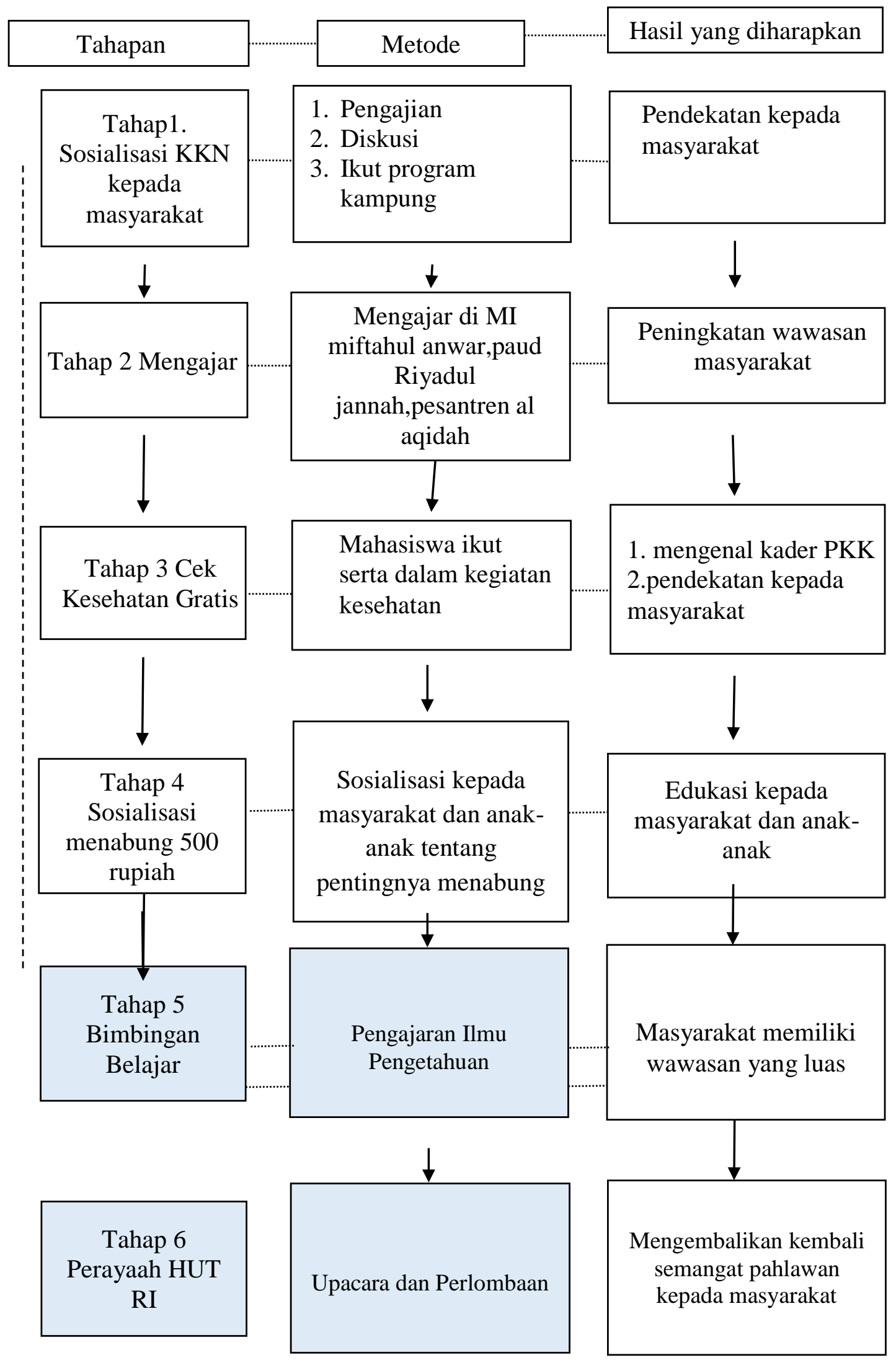




\section{Tahap 7 \\ Memperbaiki sensor LDR + membuat penerangan jalan}

\section{Tahap 8}

Seminar hukum pernikahan dini

Tahap 9

Pembukuan ke warung

\section{Tahap 10 \\ Santunan anak yatim}

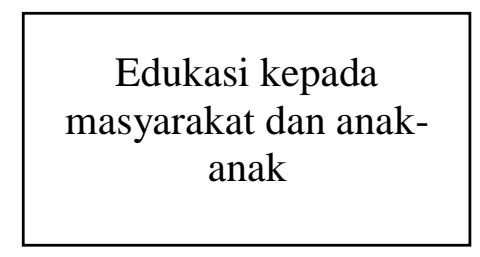

Menganalisa tempat yang kurang peneranganya lalu membuat penerangan disitu

\section{Seminar kepada} masyarakat dan pemuda

Wawancara ke setiap warung dilingkungan RW 1

Santunan,pengajian,dan perpisahan dengan warga dimasjid
Terbantu dengan adanya lampu penerangan itu

\section{Mengurangi} pernikahan di bawah umur

Terkontrolnya ekonomi warung

Mendekatkan diri kepada Tuhan yang Maha

Esa,menjadikan semangat kepada anak yatim 
Jadwal Program Kerja

\begin{tabular}{|c|c|c|c|c|c|c|}
\hline \multirow[b]{2}{*}{ No } & \multirow[b]{2}{*}{ Program Kerja } & \multicolumn{4}{|c|}{ Agustus } & September \\
\hline & & $\begin{array}{l}\text { Minggu } \\
\text { II }\end{array}$ & $\begin{array}{l}\text { Minggu } \\
\text { III }\end{array}$ & $\begin{array}{l}\text { Minggu } \\
\text { IV }\end{array}$ & $\begin{array}{c}\text { Minggu } \\
\mathrm{V}\end{array}$ & $\begin{array}{l}\text { Minggu } \\
\text { I }\end{array}$ \\
\hline 1 & Sosialisasi Program KKN & & & & & \\
\hline 2 & $\begin{array}{l}\text { Tenaga Ajar Bantuan di MI dan } \\
\text { PAUD }\end{array}$ & & & & & \\
\hline 3 & Pengajian Rutin & & & & & \\
\hline 4 & Bimbingan Belajar & & & & & \\
\hline 5 & $\begin{array}{l}\text { Melatih dan ikut upacara } \\
\text { dimasyarakat,dan Perayaan } \\
\text { HUT RI "17 Agustus" }\end{array}$ & & & & & \\
\hline 6 & $\begin{array}{l}\text { Cek Kesehetan Geratis, PHBS, } \\
\text { dan CTPS }\end{array}$ & & & & & \\
\hline 7 & Pembukuan ke warung & & & & & \\
\hline 8 & $\begin{array}{l}\text { seminar hukum tentang } \\
\text { pernikahan dini }\end{array}$ & & & & & \\
\hline 9 & $\begin{array}{llll}\begin{array}{l}\text { Santunan anak } \\
\text { perpisahan }\end{array} & & & \\
\end{array}$ & & & & & \\
\hline 10 & $\begin{array}{l}\text { Perbaikan sarana prasarana } \\
\text { penerangan jalan umum }\end{array}$ & & & & & \\
\hline 11 & Sosialisasi Menabung & & & & & \\
\hline 12 & Bazar murah & & & & & \\
\hline 13 & Sosialisasi Program KKN & & & & & \\
\hline
\end{tabular}




\section{Metode Pendekatan}

Pendekatan kekerabatan, artinya bahwa pembinaan yang dilakukan senantiasa dikaitkan dalam rangka membangun kekerabatan antar jama'ah yang semakin memudar. Dalam Kamus Besar Bahasa Indonesia (KBBI) edisi III (2005:88) menyebutkan bahwa bahasa merupakan sistem lambang bunyi yang arbitrer, yang digunakan oleh anggota satu masyarakat untuk bekerjasama, berinteraksi, mengidentifikasi diri, dan bahasa merupakan percakapan (perkataan) yang baik. Pendekatan berdasarkan karakter masyarakat, yakni pembinaan yang dilakukan akan disesuaikan dengan karakter masyarakat.

\section{Partisipasi Masyarakat dalam Pelaksanaan Program}

Partisipasi masyarakat yang dapat dilakukan dalam kegiatan ini adalah sebagai berikut:

a. Melakukan kerjasama

b. Membantu dalam setiap proker yang ingin dijalankan.

\section{REALISASI PROGRAM}

Berikut adalah capaian program yang dicanangkan melalui programprogram yang telah direncanakan:

\section{Bidang Pendidikan}

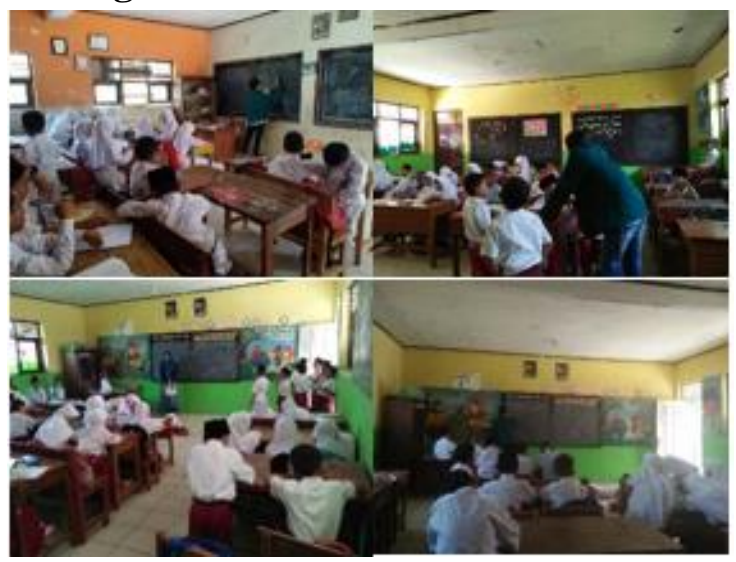

a. Mengajar di MI Miftahul anwar

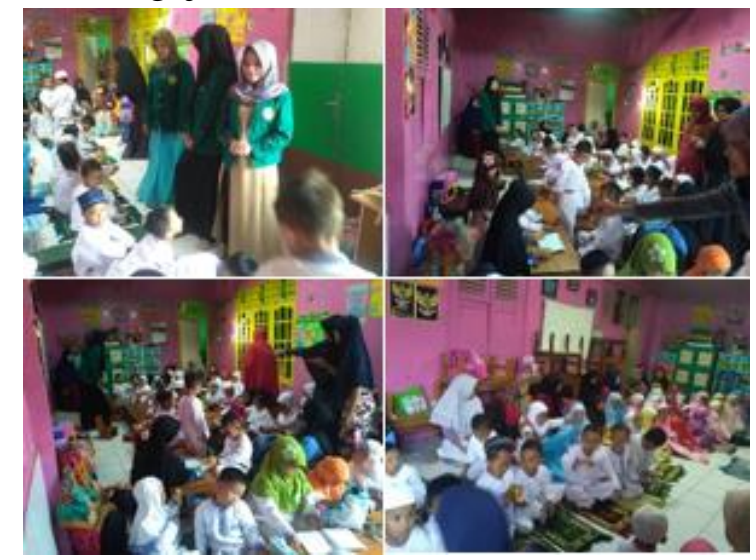

b. Mengajar di Paud

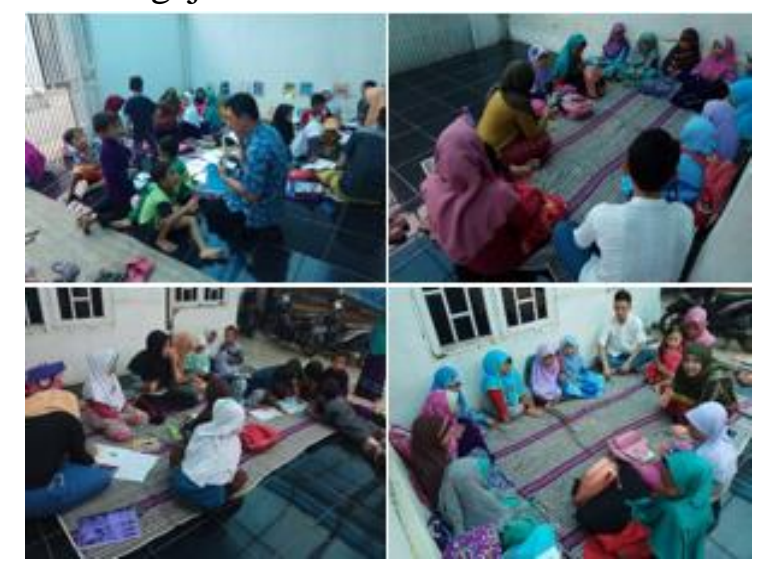

c. Membuka Rumah belajar 


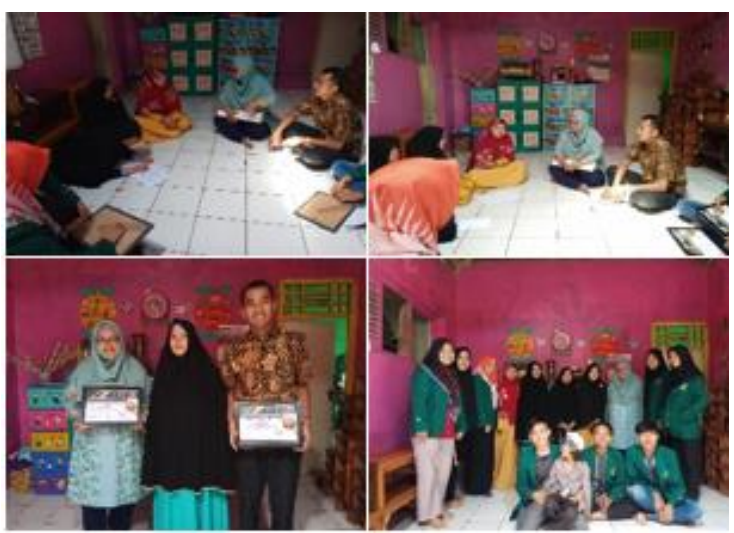

d. Melakukan pelatihan bahasa inggris pada guru paud

Pelatihan ini dilakukan untuk mengedukasi tenaga kerja PAUD dengan memberi arahan dan modul pembelajaran

\section{Bidang Agama}
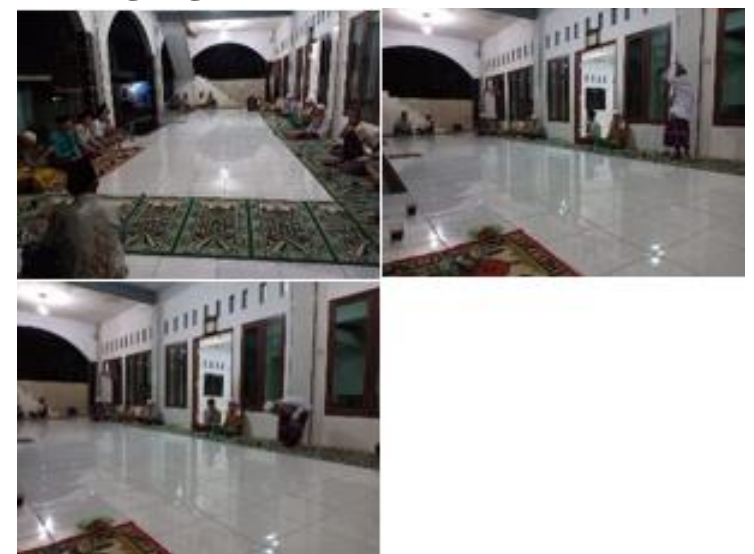

a.Pengajian Bapak-Bapak

pengajian ini dilakukan di masjid nurul fallah pada malam rabu setelah isya

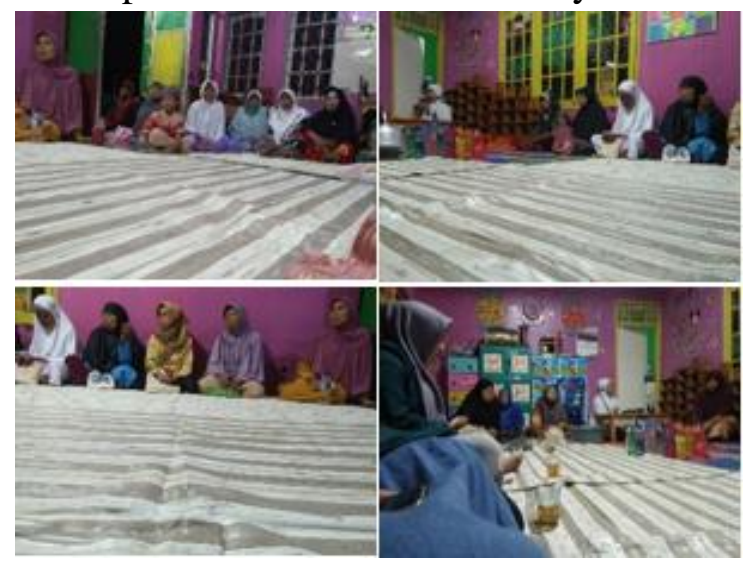

b. Pengajian ibu-ibu

pengajian ini dilakukan dipaud riyadhul jannah pada hari minggu ba'da magrib dan di paud alaqidah pada hari jumat setelah asar

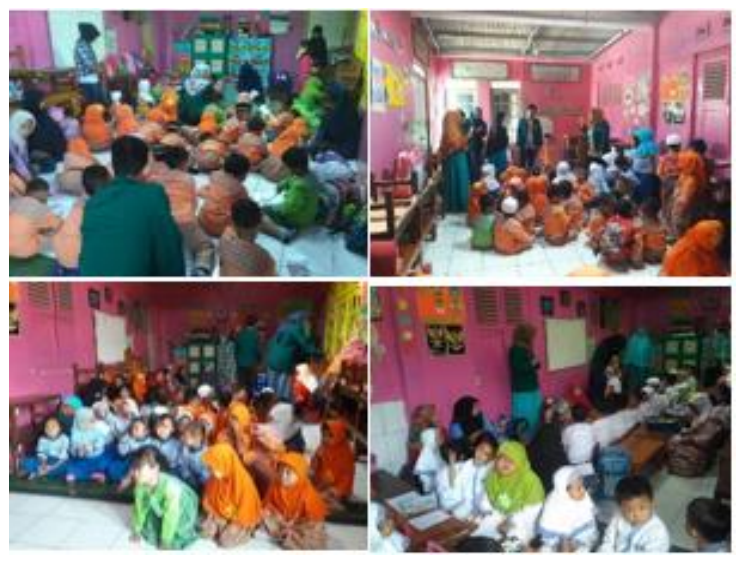

c. Mengajar TPQ

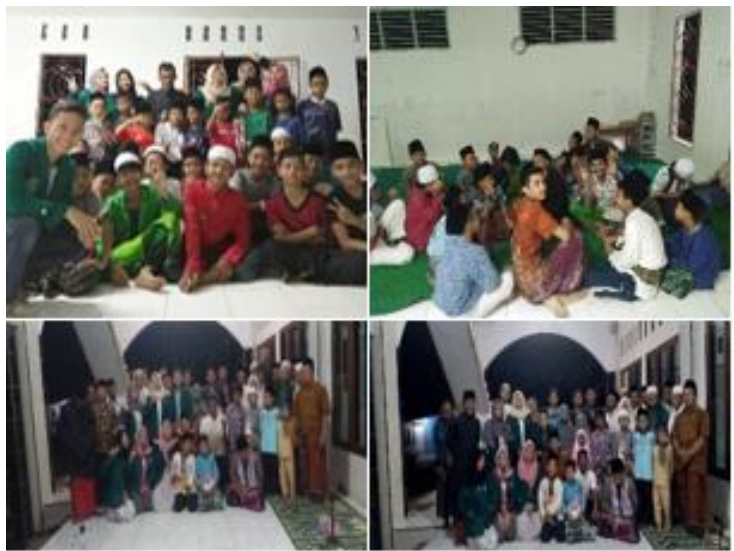

d. Mengajar Pesantren

pengajaran dimulai setelah magrib pada hari senin sampai rabu.

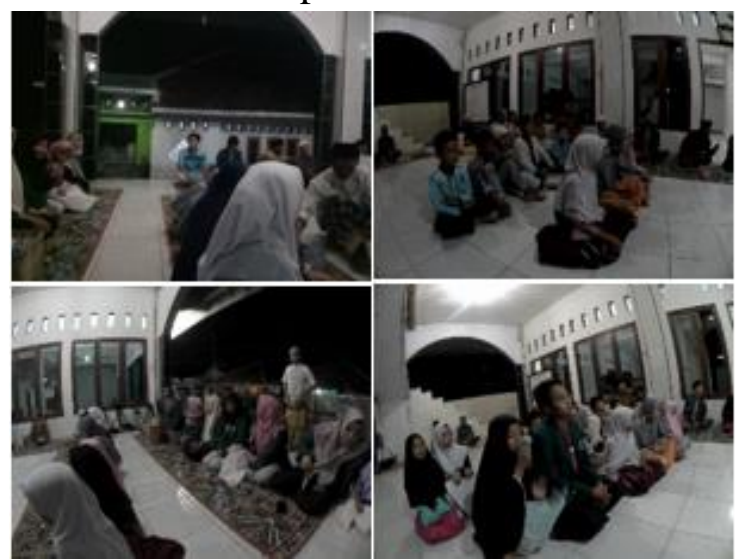

e.Santunan anak yatim + perpisahan 


\section{Bidang Kesehatan}

Menurut Eska dalam Jurnal Abdi Dosen Pemberdayaan kesehatan merupakan kegiatan penambahan pengetahuan yang diperuntukan bagi masyarakat melalui penyebaran pesan.

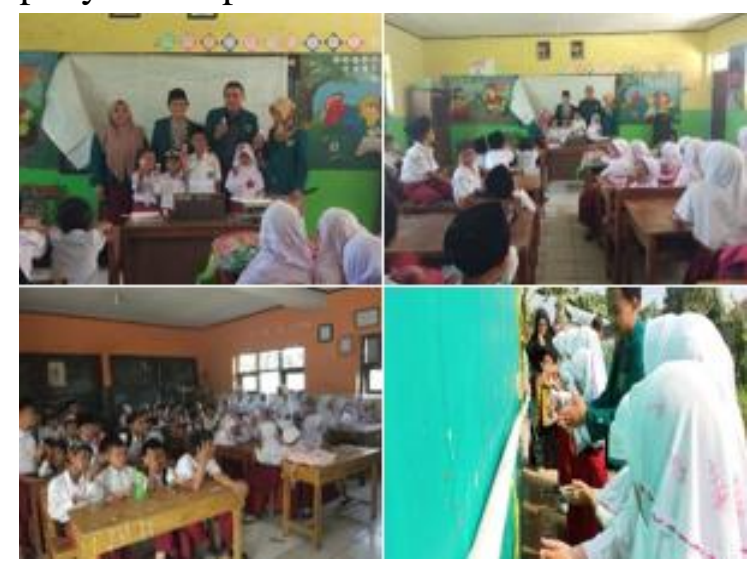

a. Penyuluhan BHBS dan CTPS penyuluhan ini dilakukan di MI miftahul anwar agar mengedukasi mereka supaya hidup bersih

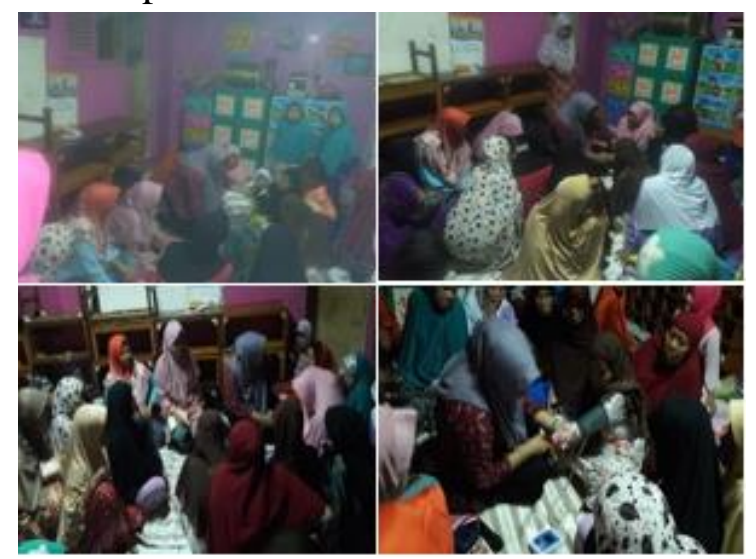

b. Tensi darah dan cek gula darah gratis dilakukan dipengajian ibu-ibu

\section{Bidang Hukum}

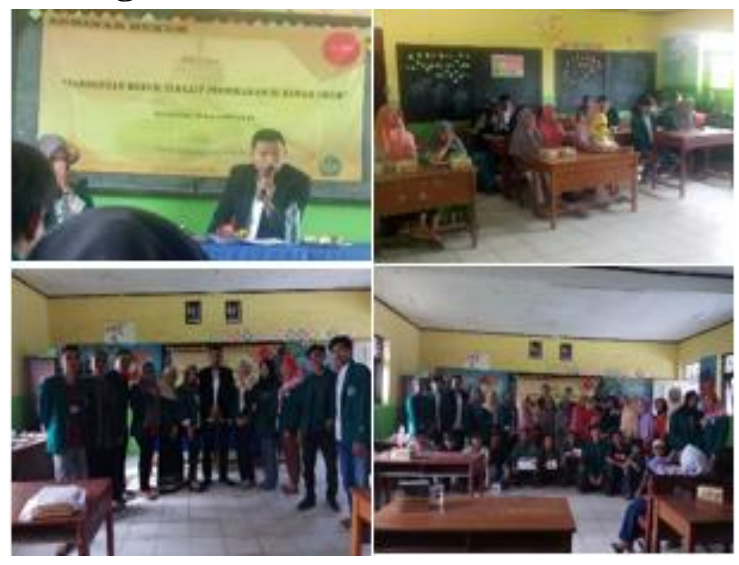

a. Seminar hukum tentang pernikahan diusia dini

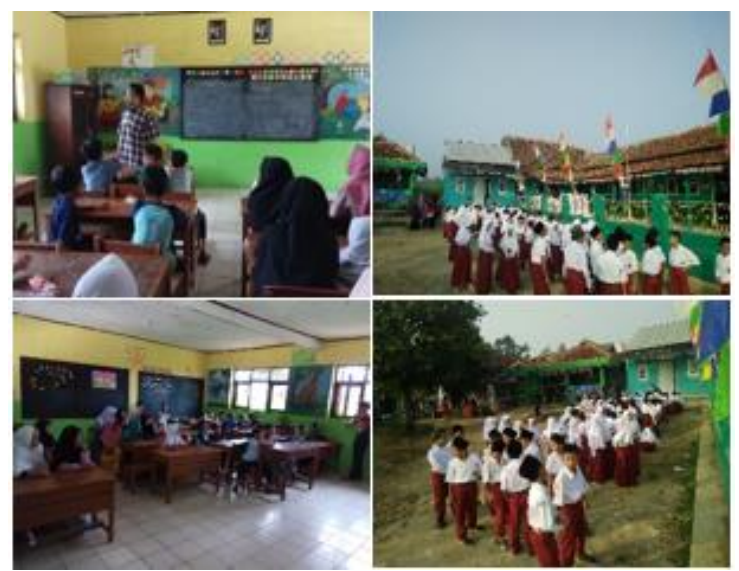

b. Mengajar upacara 17an kepada siswa MI miftahul anwar

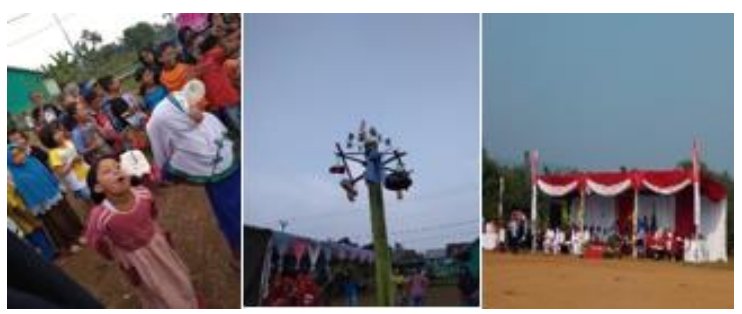

c.Upacara dan perayaan $17 \mathrm{an}$ 


\section{Bidang teknik}

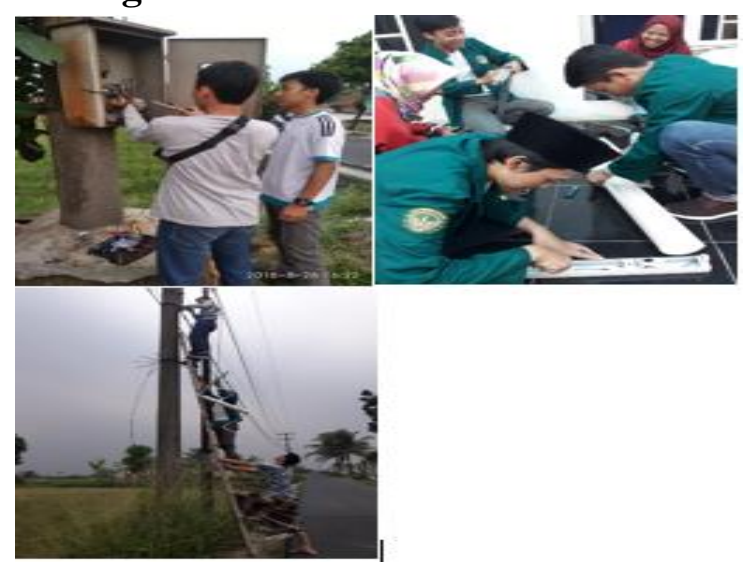

a. Membuat penerangan jalan dan memperbaiki sensor LDR

\section{Bidang ekonomi}

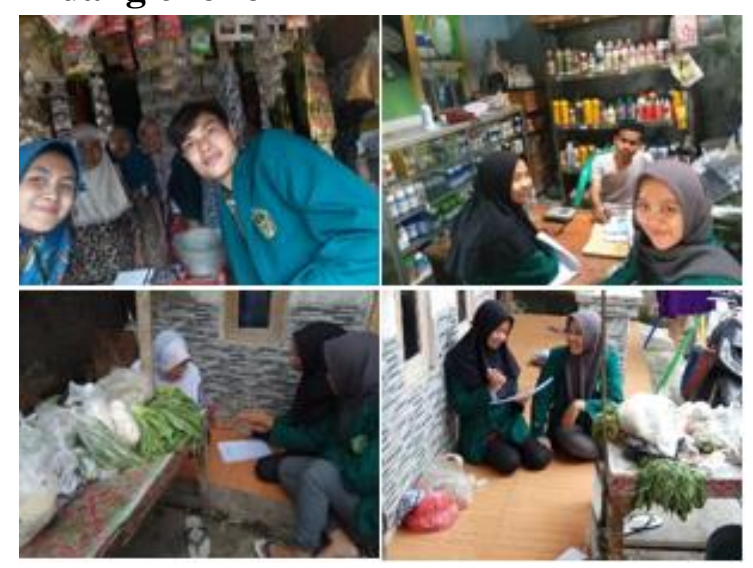

a.Pembukuan kewarung warung

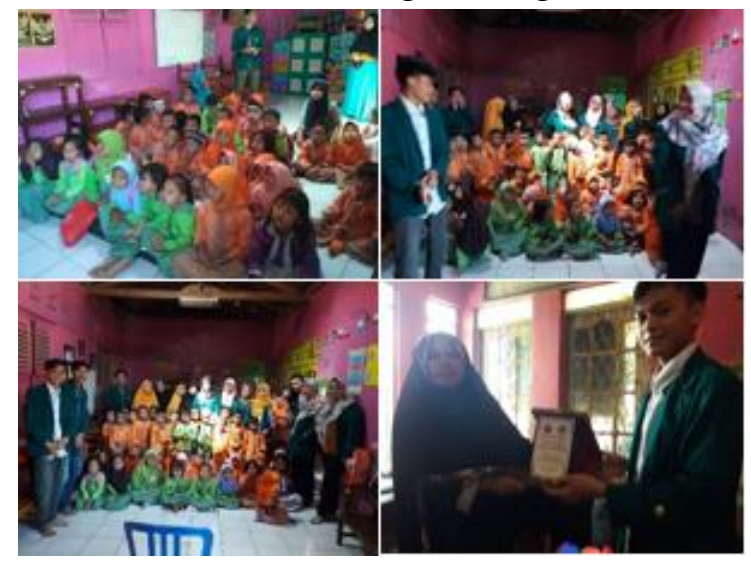

b.Sosialisasi menabung dari 500 rupiah

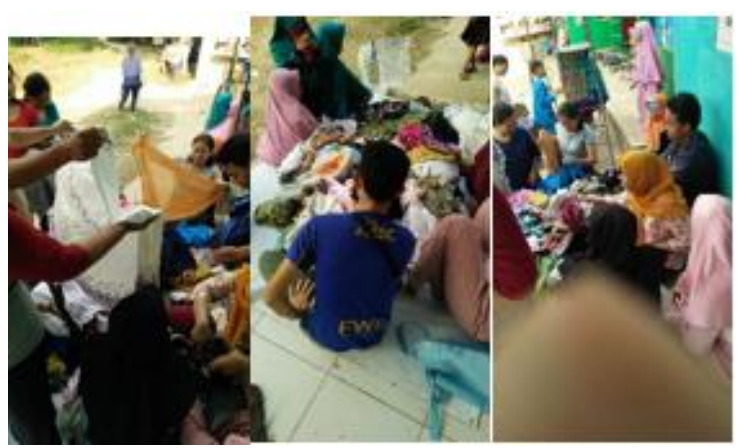

c.Bazar Murah

\section{KESIMPULAN}

Kegiatan KKN dengan sasaran Masyarakat Desa Situ Udik secara umum berjalan dengan lancar sesuai apa yang direncanakan, meski target waktu yang direncanakan tidak dapat sepenuhnya dijalankan sesuai dengan hal tersebut, namun hal tersebut tidak merubah esensi pelaksanaan program tersebut. Adapun kesimpulan dari pelaksanaan program kerja KKN masyarakat yaitu :

1. Program KKN dapat terlaksana dengan baik dan lancar meski ada beberapa perubahan dan tambahan serta waktu pelaksanaan yang kurang sesuai dengan yang direncanakan.

2. Program Kerja KKN dapat berjalan dengan baik berkat Ridho Allah, dengan perantara, dukungan dan kerja sama antar warga yang sangat membantu.

Dengan demikian, hasil kesimpulan diatas menunjukkan bahwa secara garis besar program KKN dapat dikatakan sukses dan lancar, meskipun waktunya lebih maju atau lebih mundur 
Volume 02 Nomor 03, September 2018

\section{SARAN}

Berdasarkan hasil pelaksanaan program KKN yang dilaksanakan sejak 7 Agustus 2018 sampai 5 September 2018, terdapat beberapa saran yang sekiranya membangun bagi semua pihak, antara lain :

\section{Kepada Masyarakat Desa Cinangneng}

Program-program yang telah dilaksanakan oleh mahasiswa dan masyarakat, sebaiknya ada pengembangan ataupun tindak lanjut untuk peningkatan selanjutnya.

\section{REFERENSI}

. (2018). Petunjuk Pelaksanaan KKN Tematik Terintegrasi 2018. Bogor : LPPM UIKA

.(2017). Pedoman Pelaporan PPM UIKA 2017. Bogor. LPPM UIKA

Eska Perdana Prasetya (2017), Pemberdayaan Masyarakat Tentang Kesehatan, Pendidikan Dan Kreatifitas, Jurnal Abdi Dosen

Dadang iskandar,Dede sukmana,Rahmah tullah.(2018) Meningkatkan kesadaran masyarakat akan pentingnya budaya literasi melalui berbagai media. 